Journal of Southeast Asian

\title{
Selected Poems: động-quan; your name won't be engraved, Grandma; the peace generation; foreigners at home, forging the Vietnamese diasporas; i can't help but keep asking
}

Trangdai Glassey-Tranguyen

Founder \& Director, Vietnamese Diaspora Projects, vietamproj@gmail.com

Follow this and additional works at: https://docs.lib.purdue.edu/jsaaea

\section{Recommended Citation}

Glassey-Tranguyen, Trangdai (2013) "Selected Poems: động-quan; your name won’t be engraved, Grandma; the peace generation; foreigners at home, forging the Vietnamese diasporas; i can't help but keep asking," Journal of Southeast Asian American Education and Advancement. Vol. 8 : Iss. 1, Article 13. DOI: $10.7771 / 2153-8999.1068$

Available at: https://docs.lib.purdue.edu/jsaaea/vol8/iss1/13

This document has been made available through Purdue e-Pubs, a service of the Purdue University Libraries. Please contact epubs@purdue.edu for additional information.

This is an Open Access journal. This means that it uses a funding model that does not charge readers or their institutions for access. Readers may freely read, download, copy, distribute, print, search, or link to the full texts of articles. This journal is covered under the CC BY-NC-ND license. 


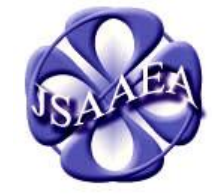

Volume 8 (2013)
A peer-reviewed scholarly journal published by the National Association for the Education \& Advancement of Cambodian, Laotian, and Vietnamese Americans (NAFEA)

\section{động-quan (*)}

Oh, pain!

Such pain!

Pain for my child!

Or is my child in pain?

you tore my flesh, beloved, and walked on without embalming

no casket

no mourners

no candle, no flowers

no incense, no final rituals

you tore my flesh, beloved, and walked on

my uterus shivered

my soul interred its face

my heart tried to hold on

my bosom in still death

my body stoned

you tore my flesh, beloved, and walked on

what do i say at goodbye?

what words of counsel?

attachment lost lingering

you tore my flesh, beloved,

\section{Selected Bilingual Poems}

by
Trangđài Glassey-Trầnguyễn

Founder \& Director, Vietnamese Diaspora Projects 
and walked on

động-quan

heading home

my womb becomes your tomb

burying your corpse, bright red

you tore my flesh, beloved,

and walked on

half of my soul stays

following your footprints

loving you for the rest of this life

(*) Roughly translated as 'the transfer of the casket,' 'động-quan' is only a single step in the days-long structure of grief that allow the family of a deceased to carry out the final rituals for a loved one while coming to terms with the loss. In Vietnam, the casket would be placed in the home for visits, viewing, and final rites before being transferred to the cemetery. As such, 'đọngquan,' literally 'stirring the casket,' is the first time the deceased leaves the home after death, and will subsequently stay in the new 'home' gravesite. Here, my womb serves as both the home and the casket to my deceased fetus, and symbolically as her final resting place as well.

\section{động quan}

Đau!

Ôi đau!

Đau cho con!

Hay con đau?

con xé thịt

bước đi

không tẩn liệm

không mồ mả

không người đưa tiễn

không nến, không hoa

không nhang đèn, nghi thức

con xé thịt

bước đi

tử cung mẹ rùng mình

tâm tư mẹ bưng mặt

cõi lòng mẹ lất lay

trái tim mẹ chết đứng

cả người mẹ lặng câm

con xé thịt

bước đi

mẹ nói gì tiễn biệt? 
dặn dò gì chia tay?

lưu luyến chừng thất lạc

con xé thịt

bước đi

động quan

di về cõi

lòng mẹ hóa mộ bia

chôn xác con đỏ ối

con xé thịt

bước đi

mẹ nửa hồn ở lại

dõi theo vết chân con

suốt đời này thương mãi

(*) Một nghi thức trong chuỗi ngày tang niệm, động quan là giây phút dời thi thể của ngườ quá cố tù nhà ra mộ sau nhũng nghi thức cuối cùng. Ở Việt Nam, người chết được liệm trong quan tài và giữ tại nhà để thân bằng quyến thuộc đển viếng. Động quan là lần đầu tiên di thể rời nhà, để đi về ngôi 'nhà' mới, tức mộ phần. Ở đây, cung lòng tôi chính là nhà, là quan tài cho thai nhi yểu mệnh, và cũng là biểu tượng cho nơi yên nghỉ sau cùng của con tôi. 


\section{your name won't be engraved, Grandma}

your name won't be engraved

on a plaque, a shrine, a gate;

like countless Vietnamese grandmas

your name will just stay

in memories

of your loved ones

till the memories

no longer migrate

across the generations

and no longer resonate

with the new lives

who descend from your descents

your name won't be engraved

in documents with great honor

where people are commemorated

over and over again

for something great they did

but hadn't you done

so many things, brave and great?

your name won't be engraved

except on your permanent home

stating that your beloved husband

had erected it

in your honor

in his pain

but who cares

if your name won't be engraved?

you lived a good life

you survived wars

you managed to find peace

you had returned home

sinh ký tử quy

any engravement

will eventually pass

why linger?

you wouldn't.

\section{tên Ngoại sẽ không được chạm, được khắc}

tên Ngoại sẽ không được chạm, được khắc

trong văn bằng, trong miếu, trên cồng; 
như hàng triệu những bà Ngoại Việt Nam khác

tên Ngoại sẽ chỉ ở lại

trong ký ức

của những người thân yêu

cho đến khi những ký ức ấy

thôi di chuyển

xuyên các thế hệ

và không còn âm vang

trong những mầm sống mới

những hậu duệ của hậu duệ của Ngoại

tên Ngoại sẽ không được ghi, được chạm

trong những văn bằng tuyên dương

như người ta vẫn tưởng niệm đi

tưởng niệm lại

một ai đó vì một điều cao cả họ đã làm

nhưng không phải chính Ngoại

cũng đã làm bao điều can đảm và cao cả sao?

tên Ngoại sẽ không được chạm, được khắc

ngoại trừ trên ngôi nhà vĩnh viễn

nơi có ghi: do chính hiền phu

lập mả

trong sự tương kính Ngoại

trong nỗi đau của Ông

nhưng có sao đâu

nếu tên Ngoại không được chạm, được khắc?

Ngoại đã qua một cuộc đời tốt đẹp

đã sống sót chiến tranh

đã tìm được bình an

đã trở về

sinh ký tử quy

bất cứ việc chạm khắc nào

rồi cũng qua đi

việc gì phải lưu luyến?

Ngoại thì không. 


\section{the peace generation}

the world called us

"the peace generation"

those born after the fifteen centuries of war-torn Vietnam

after April 1975

an ending

of many beginnings

undecided

the end of a war without history

the end of an Asian tiger, of the Pearl of the Far East

the instigation of an era in exile

the instigation of humanity on trial

1975-1994

a nineteen-year fiasco

i discern the hues and chords of peace

mixed and matched

the peace my friend knows

fighting the smoldering sun

biking to school day in day out

two hours each way

taking in engine smoke, inhaling street dust

cohorts in my maternal hometown

walk three hours straight yet arriving at school

when the tide brims, it takes some away

they float in the river

no stiff in sight

kids in my town

read life, but not a half letter,

take charge of their daily excursion to catch miniature crabs

half is cooked for the family's meals

half is sold to feed to ducks

competing political convictions still unrest

warring ideologies at our backs

we dash, out of breath

only to be seized

in the noose drawing tight

the amorphous lariat

my friend 
hay roof, mud wall

works the deep field, the low patch

her mother works the bike to teach in the other village

two hours through the soil path, one hour bobbing the rock road

now laid off

her father was in the reserved army

where he once got lost in the soil, unearthed thereafter

half mad half dead, a terrorist at home

the day she graduated high school

the mother found a match

to marry her off to an Australian expatriate

in hope of her better future

leaving her first love

my friend filed the immigration paper

till she can no longer bear it

and turns lunatic

the farmers in my town

plow and plant

a life of toil, poverty-struck

i mind not their backbreaking work

but the absurdity of their barren stomach

breaks my heart

life

- angst-ridden

when temples

turn commune's work place

shrines and tombs

serve as local headquarters

- troubled

when the domestic authority

seize the house of worship

during the canonization of 117 Vietnamese martyrs

keeping out church members, barricading them from visiting and praying

and at each solemn mass

plain-clothed cops mingle in the only church in town

to single out the faces of teachers and government workers

to execute elimination

my friends in Vietnam these days

still fight each other for the green dollar

still at odd with the rice pot everyday

my friends, the outstanding students of the whole province,

are occupied with earning enough to send Mom-home the monthly rice

a generation negotiating peace with bread and dress 
how poverty lives well

since the French colonization

now evermore impecunious

farmers renting land,

farmers taxing life

lush rice fields

withered souls

they suffer in solitude

to give my generation an era of silenced peace

our peace is the rice seed

choked in the forestry of thorns

stunted,

putrefied

huffing

who said we have peace?

who said we have peace?

who said we have peace?

oh, peace, how do Thee define thyself?

would Thee ever reify my life...?

"no justice, no peace!

no justice, no peace!

no justice, no peace!"

\section{thế hệ hòa bình}

thế giới gọi chúng tôi là

"thế hệ hòa bình"

những con người được sinh ra sau mười lăm thế kỷ binh đao của một Việt Nam tan tác

sau tháng Tư 1975

một kết thúc

của nhiều bắt đầu

vô định

kết thúc của một cuộc chiến không có lịch sử

kết thúc của một con rồng Á Châu, của Hòn Ngọc Viễn Đông

khởi đầu của một thời đại lưu vong

của thủ mưu đưa nhân sinh lên bàn mổ, của nhục nhằn nhân bản

1975-1994

mười chín năm chao đảo bấn loạn

tôi nếm cái âm cái sắc của hòa bình 
lẫn lộn vàng thau

cái hòa bình của bạn tôi

vất vả chống chọi mặt trời chang chang nắng

đạp xe đến trường ngày này qua ngày khác

hai tiếng mỗi bận

nuốt vào khói xe, hít lấy bụi đường

mấy đứa ở quê ngoại

đi bộ già ba tiếng còn chưa thấy cổng trường

mùa nước lên cuốn đi ít đứa

chết trôi sông

mất xác

con nít quê tôi

sõi đời, chữ cắn đôi không biết

mỗi ngày xông xáo vô bưng bắt còng bắt cáy

phân nửa rang muối cả nhà cơm mỗi bữa

phân nửa cân bán cho vịt xơi

những chính kiến đối lập vẫn xâu xé nhau

những tranh chấp ý thức hệ luôn săn đuổi

chúng tôi chạy hụt hơi

mà vẫn không thoát

cái thòng lọng

vô hình

bạn tôi

chòi tranh, vách đất

cày sâu cuốc bẩm

mẹ nó cưỡi ngựa sắt đi dạy ở xã bên cạnh

dài hai tiếng đồng hồ đường đất, lộc cộc một tiếng đồng hồ đường đá

mà vẫn bị giảm biên chế

ba nó hồi đó đi bộ đội

bị đất vùi, sau moi lên được

dở khùng dở chết, khủng bố vợ con

ngày nó ra trường trung học

mẹ nó mai mối

gả nó cho Việt kiều bên Úc

mong thân nó đỡ khổ

nó bỏ người yêu đầu đời

để làm giấy hôn thú xuất ngoại

rồi không chịu nổi

nó phát điên

nông dân quê tôi 
cấy cày

cần lao một đời, đói trắng

tôi không đau cái quần quật của họ

mà chẳng cam cái lủng bao tử triền miên

vô nghĩa ấy

đời

oán than

khi chùa chiền

biến thành sân phơi hợp tác xã

lăng miếu

hóa trụ sở ủy ban nhân dân

bất an

khi 117 vị tử đạo Việt Nam được phong thánh

công an phường

bố ráp nhà thờ

đảo trước áp sau không cho con chiên viếng thăm, cầu nguyện

mỗi dịp lễ lớn

người ta vẫn đi lùng trong ngôi thánh đường duy nhất trong thị trấn

khuôn mặt của công nhân viên, giáo chức

để hôm sau khai trừ

bạn bè tôi ở Việt Nam giờ

vẫn đánh nhau với đồng đô la xanh

vẫn tranh chấp với nồi cơm mỗi bữa

bạn tôi, những sinh viên ưu tú của tỉnh Tiền Giang

không nghĩ gì hơn là làm sao đủ tiền cơm gửi về quê cho mẹ, mỗi tháng

một thế hệ tranh thủ hòa bình với vá áo túi cơm

mà vẫn nghèo

nghèo từ cái thời Pháp thuộc

giờ càng điêu đứng

nông dân đi thuê đất,

nông dân đóng thuế đời

lúa xanh rì

người héo hắt

họ khổ không trách không than

cho thế hệ tôi nền hòa bình câm nín

hòa bình của chúng tôi là hạt lúa

bị xiết giữa rừng gai

thui chột,

mai một

ngóp

ai bảo chúng tôi có hòa bình? 
ai bảo chúng tôi có hòa bình?

ai bảo chúng tôi có hòa bình?

hòa bình ơi, Người có bao nhiêu cái định nghĩa?

có định nghĩa nào làm rõ được đời tôi...?

"không công lý, sao có hòa bình!

không công lý, sao có hòa bình!

không công lý, sao có hòa bình!" 


\section{foreigners at home, forging the Vietnamese diasporas (aka Proclamation of a Diasporic Self)}

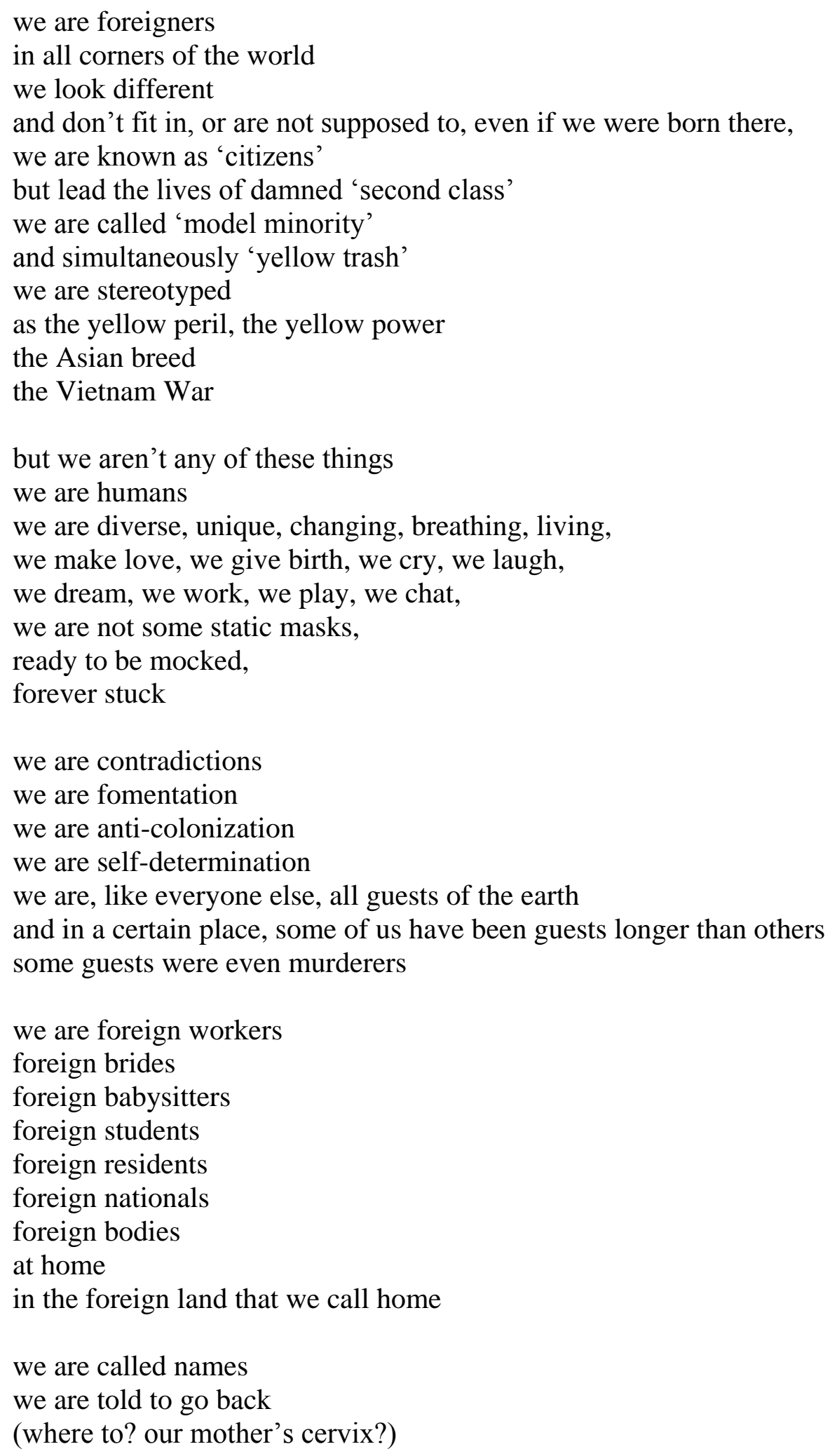


we are ridiculed, poked fun of, we are 'different' even if we speak English (or the respective local language)

without an accent

but our biological makeup

is the blame for all of the disruptions we don't cause,

but still get credit

or is it your prejudice?

we are foreigners

in our own backyard

trying to figure out

where we had come from

and where we are heading

while the whole world

doesn't stop spinning, moving, swapping bodies and stories

we are foreigners

wherever we are

com on, lift your glass, and sip a toast

to all the foreigners seeking home

in the Vietnamese diasporas!

be home! and ride on!

your curfew is naught.

\section{ngoại kiều tại nhà, thiết kế thế giới Việt hải ngoại} (aka Tuyên Ngôn tự bạch của một kẻ ngoại biên)

chúng tôi là ngoại kiều

ở khắp nơi trên thế giới

chúng tôi không giống ai

và không hội nhập được, hay không được phép hội nhập, cho dù chúng tôi sinh ra ở đó, chúng tôi là 'công dân'

nhưng phải đứng hạng hai

chúng tôi được gọi là 'thiểu số mẫu mực'

nhưng cũng bị kêu 'da vàng rác rưởi'

chúng tôi bị quơ đũa cả nắm

là cơn dịch hạch da vàng, quyền lực da vàng

bọn Á châu

cuộc chiến Việt Nam

nhưng chúng tôi không là những thứ này

chúng tôi là con người

chúng tôi đa dạng, vô song, biến chuyển, đang thở, đang sống,

chúng tôi làm tình, sinh con, biết khóc, biết cười, 
chúng tôi có hoài bão, làm việc, vui chơi, trò chuyện,

chúng tôi không là những mặt nạ cứng khô,

sẵn sàng chờ bị phỉ báng,

ngàn đời mắc kẹt

chúng tôi là những mâu thuẫn

chúng tôi là men muối

chúng tôi chống đô hộ

chúng tôi tự cường

chúng tôi, giống như tất cả mọi người khác, là khách trên mặt đất

và ở một nơi nhất định, người này đã làm khách lâu hơn người kia

có nhiều vị khách còn là kẻ giết người

chúng tôi là công nhân ngoại quốc

cô dâu ngoại quốc

vú em ngoại quốc

sinh viên du học

thường trú nhân ngoại quốc

ngoại kiều

những cơ thể ngoại quốc

tại nhà

trên những miền đất lạ chúng tôi gọi là nhà

chúng tôi bị chửi rủa

chúng tôi bị đuổi về

(về đâu? tử cung của mẹ?)

chúng tôi bị lăng mạ, mỉa mai,

chúng tôi 'khác người'

ngay cả khi chúng tôi nói tiếng Anh (hay một ngôn ngữ địa phương nào đó)

không bị lai giọng

nhưng cái cấu tạo sinh thể của chúng tôi

là cái cớ để chúng tôi bị kết án cho những cái gẫy đổ

mà chúng tôi không tạo ra

hay đó là sự kỳ thị của quý vị?

chúng tôi là người ngoại quốc

ngay trong sân nhà mình

cố tìm hiểu xem

mình đã đến từ đâu

và đang đi về đâu

trong khi cả thế giới

vẫn không ngừng xoay, dịch, trao đổi con người và kinh nghiệm

chúng tôi là ngoại kiều

ở bất cứ nơi nào

thôi nào, xin nâng ly của quý vị, và nhấp môi 
chúc lành cho tất cả những ngoại kiều đang tìm lối về trong thế giới Việt hải ngoại!

hãy về! và hãy khởi hành!

đã không còn giới nghiêm. 


\section{i can't help but keep asking \\ * about the orthopedic program of SAP-VN (Social Assistance Program for Vietnam)}

five fingers

melting into one

what've you got

for a grip crossing the bamboo pole ${ }^{1}$ ?

the arms short,

the elbows sad, reversed

they are stubborn

heeding not your commands

your legs shrunk

have yet risen once

bones and skin deformed, in mutual denial

they disagree, leaving you straitened

your sense of disability flutters

your four limbs speak different languages

your life paralyptic, dragging along

the agony grows on your hair

inundating you in a marginalized identity

your sleep unsound, your wake like a spineless bamboo

crawling round at the foot of the society

searching for home in vain

who is responsible

for your sufferings?

do i sue this life,

hatred, or wars?

i can't help asking

why you are disabled?

and why penury keeps stalking you...

i can't help asking:

why you must wait

all of these years

for a surgery

to be free

so that with the first time you rise

your life is clothed in the silk of humanity

\footnotetext{
${ }^{1}$ Some bridges in Vietnam are simply made out of a bamboo pole. To cross, one needs to hold fast to the supporting rail above the bridge.
} 
the belated steps

filled with hope

let us help you

make a first attempt

the hesitant steps

post-surgery

may you walk with poise

into life

tôi cứ phải hỏi...

* về chuoong trình giải phẫu chỉnh hình của SAP-VN

tay năm ngón

tan vào thành một

em lấy gì

bấu víu giữa cầu tre

cánh tay đoản,

khủy tay buồn, lật ngược,

nó cứng đầu

nên em bảo, chẳng nghe

chân cong quíu

chưa một lần đứng dậy

xương và da dị dạng, khước từ nhau

chúng bất hòa, nên em còn lầm lũi

mỗi một ngày niềm khuyết tật bôn ba

tứ chi em đã bất đồng ngôn ngữ

cuộc đời em vẫn bất toại, lết la

nỗi tủi hờn ngày đêm mọc trên tóc

xõa trên em một căn cước bên lề

ngủ không lành,

thức không khỏi hẩm hiu

em vẫn sống như cây tre mất cật

bò quanh chân xã hội

lất lây về

tôi bắt tội ai

cho những đọa đày em chịu?

tôi kiện cuộc đời,

thù hận, hay chiến tranh?

tôi cứ phải hỏi

vì sao em tàn tật? 
và vì sao nghèo đói mãi bám chân...

tôi cứ phải hỏi:

vì sao em phải đợi

bao tháng năm rồi

chờ giải phẫu

hóa thân

để một bước đầu tiên em chỗi dậy

là một ngày đời óng ả ánh nhân

những bước chân muộn màng

đầy hy vọng

hãy cho em

được cất bước một lần

những bước chân ngập ngừng

sau giải phẫu

hãy cho em kiên vững

bước vào đời

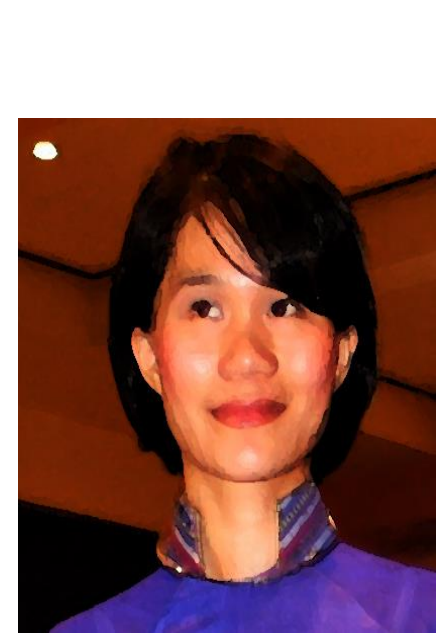

\begin{abstract}
About the Author
Trangđài Glassey-Trầnguyễn is the sole scholar having conducted hundreds of oral history interviews and multi-sited research on the Vietnamese diasporas in the U.S., Europe, Australia, and Asia since the 1990s. As the first scholar to conduct extensive fieldwork and oral history projects in Little Saigon, Orange County, California, Trangdai received several awards for her studies, and was the winner for the 2004 CSU-system Student Research Competition, Graduate level, with the entry "Orange County, Yellow History: An Intimate Encounter with Vietnamese American Lives" based on the Vietnamese American Project. A celebrated and syndicated bilingual author, Trangdai has published over 400 creative and critical works in
\end{abstract} academic journals, anthologies, edited volumes, and the media. An exceptional-ranking Fulbright scholar, she started the very first oral history project on the Vietnamese populations in Sweden in 2004. Trangdai holds an M.A. in History from CSU Fullerton, an M.A. in Anthropology from Stanford University, and is working toward her Ph.D. 


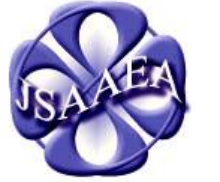

Volume 8 (2013)

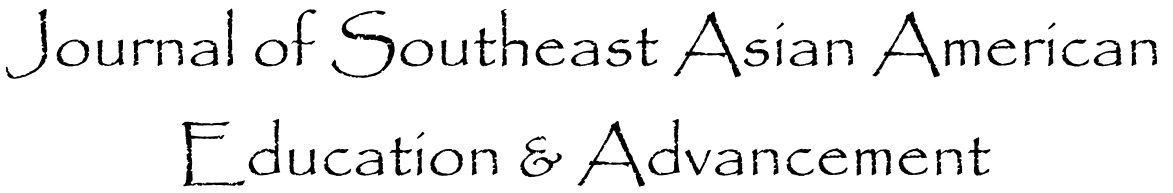

WwW.JSAAEA.org

\author{
Editor \\ Dr. Wayne E. Wright \\ University of Texas at San Antonio \\ Associate Editors \\ Dr. Chhany Sak-Humphry \\ University of Hawaii at Manoa \\ Dr. Phitsamay Sychitkokhong Uy \\ University of Massachusetts, Lowell \\ Book Review Editor \\ Dr. Vichet Chhuon \\ University of Minnesota \\ Creative Works Editor \\ Bryan Thao Worra \\ Lao Assistance Center \\ Special Advisor \\ Gregory Green \\ Curator, Echols Collection on Southeast Asia, Cornell University Library \\ Journal Manager \\ Yeng Yang \\ University of Texas at San Antonio
}

Comments and questions for the editorial staff may be directed to jsaaea@ lists.sis.utsa.edu

\title{
Editorial Review Board
}

\author{
Dr. Steve Arounsack \\ California State University, Stanislaus \\ Dr. Phala Chea \\ Lowell Public Schools \\ Dr. Loan Dao \\ University of Massachusetts, Boston \\ Dr. Changming Duan \\ University of Missouri, Kansas City \\ Dr. Jeremy Hein \\ University of Wisconsin - Eau Claire \\ Dr. Samlong Inthaly \\ Minneapolis Public Schools \\ Dr. Ketmani Kouanchao \\ Mr. San Jacinto College
}

\author{
Dr. Carl L. Bankston III \\ Tulane University \\ Dr. George Chigas \\ University of Massachusetts, Lowell \\ Dr. Hien Duc Do \\ San Jose State University \\ Dr. Sophal Ear \\ U.S. Naval Postgraduate School \\ Dr. Nancy H. Hornberger \\ University of Pennsylvania \\ Dr. Peter Nien-Chu Kiang \\ University of Massachusetts, Boston \\ Dr. Kevin K. Kumashiro \\ University of Illinois, Chicago
}

A peer-reviewed

scholarly journal published by the

National Association

for the Education \&

Advancement of

Cambodian, Laotian,

and Vietnamese

Americans (NAFEA) 


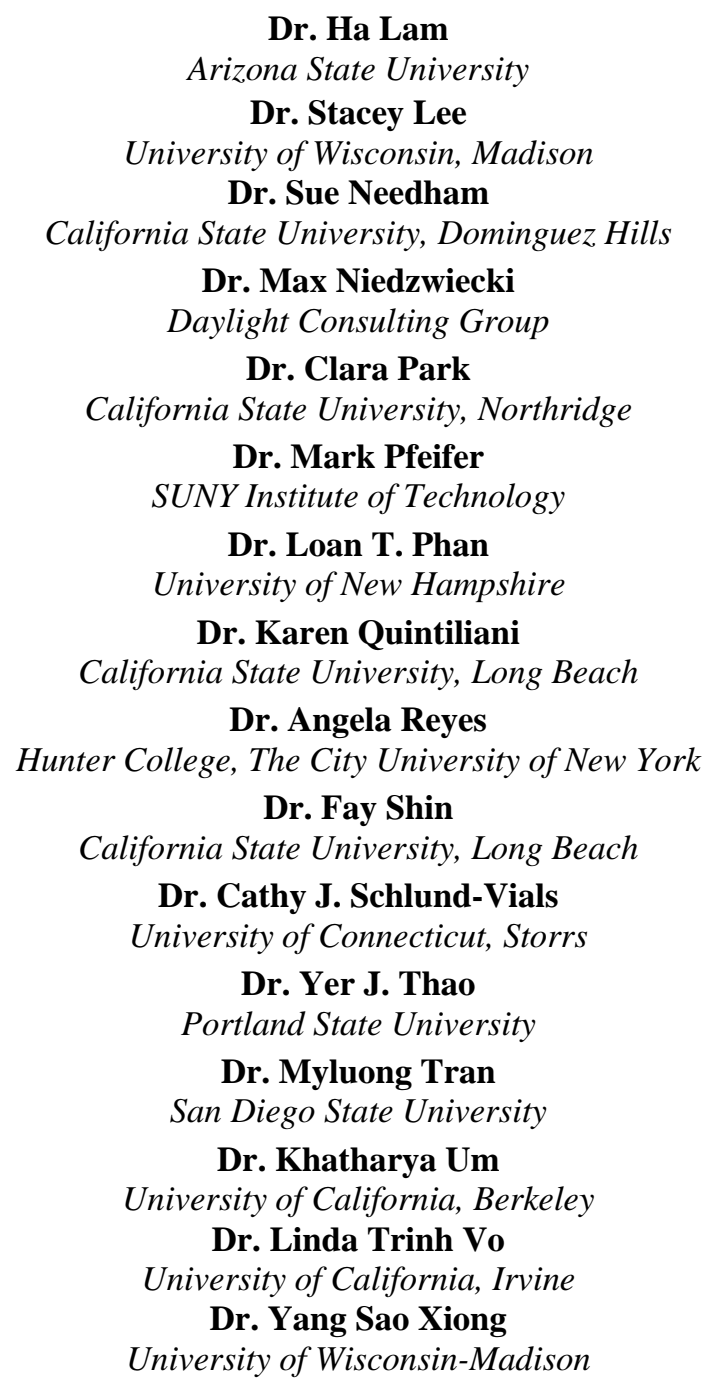

Dr. Ha Lam

Arizona State University

Dr. Stacey Lee

University of Wisconsin, Madison

Dr. Sue Needham

California State University, Dominguez Hills

Dr. Max Niedzwiecki

Daylight Consulting Group

Dr. Clara Park

California State University, Northridge

Dr. Mark Pfeifer

SUNY Institute of Technology

Dr. Loan T. Phan

University of New Hampshire

Dr. Karen Quintiliani

California State University, Long Beach

Dr. Angela Reyes

Hunter College, The City University of New York

Dr. Fay Shin

California State University, Long Beach

Dr. Cathy J. Schlund-Vials

University of Connecticut, Storrs

Dr. Yer J. Thao

Portland State University

Dr. Myluong Tran

San Diego State University

Dr. Khatharya Um

University of California, Berkeley

Dr. Linda Trinh Vo

University of California, Irvine

Dr. Yang Sao Xiong

University of Wisconsin-Madison

Dr. Jonathan H. X. Lee

San Francisco State University

Dr. Monirith Ly

Texas State University-San Marcos

Dr. Bic Ngo

University of Minnesota

Dr. Leakhena Nou

California State University, Long Beach

Dr. Isabelle Thuy Pelaud

San Francisco State University

Dr. Giang Pham

University of Minnesota

Dr. Bounlieng Phommasouvanh

Minnesota Department of Education

Dr. Kalyani Rai

University of Wisconsin, Milwaukee

Dr. Soveacha Ros

Royal University of Phnom Penh

Dr. Nancy J. Smith-Hefner

Boston University

Dr. Christine Su

Ohio University

Dr. Loan Tran

University of California, Riverside

Dr. Tinou Tran

Alief Independent School District

Dr. Silvy Un

Frost Lake Elementary School

Dr. Terrence G. Wiley

Center for Applied Linguistics

Dr. Zha Blong Xiong

University of Minnesota

Dr. Kou Yang

California State University, Stanislaus

\section{Doctoral Student Editorial Review Board}

Sovicheth Boun

University of Texas at San Antonio

Keo Chea-Young

University of Pennsylvania

Peter Tan Keo

Columbia University

Minh Mai

University of Wisconsin-Madison

Hoa Nha Nguyen

Boston College

Vanna Som

Harvard University
Virak Chan

University of Texas at San Antonio

Annie BichLoan Duong

San Joaquin County Office of Education

Ravy Lao

University of California, Santa Barbara

Thien-Huong Ninh

University of Southern California

Malaphone Phommasa

University of California, Santa Barbara

Alisia Tran

University of Minnesota

Krissyvan Truong

Claremount Graduate University 